\title{
Introduction on $\mathrm{CO}_{2}$ Geological Storage. Classification of Storage Options
}

\author{
T. Wildenborg' ${ }^{1}$ and A. Lokhorst ${ }^{1}$ \\ 1 TNO Science and Industry, PO Box 342, 7300 AH Apeldoorn - The Netherlands \\ e-mail: ton.wildenborg@ino.nl - ad.lokhorsł@tno.nl
}

\begin{abstract}
Résumé - Introduction au stockage géologique du $\mathrm{CO}_{2}$ - Classification des options de stockage Après les étapes de capture et de transport, le $\mathrm{CO}_{2}$ est stocké dans des formations géologiques. Cet article présente les différentes options de stockage : les réservoirs d'hydrocarbures déplétés, les aquifères salins profonds, les veines de charbon, les cavernes et les mines. Chaque option fait l'objet d'un article détaillé.
\end{abstract}

\begin{abstract}
Introduction on $\mathrm{CO}_{2}$ Geological Storage - Classification of Storage Options - Following the capture and transport processes, $\mathrm{CO}_{2}$ is stored in geological formations. This paper reviews the various underground storage options: depleted oil and gas reservoirs, deep saline aquifers, deep seated coal beds, caverns and mines. Each option is detailed in a separated paper following this introduction.
\end{abstract}

\section{SCOPE}

The energy consumption of the world is still depending on fossil fuels and will continue to be so for a long time yet to come. However, the use of fossil fuels has led to a significant increase in the amount of carbon dioxide in atmosphere, contributing up to $50 \%$ of the greenhouse effect. Other major greenhouse gases are nitrous oxide, CFCs, methane and ozone. The combustion of fossil fuels is responsible for $73 \%$ of the carbon dioxide production. The other main source is deforestation (25\%). Consequently, the development of greenhouse gas mitigation technologies plays an important role as a potential response to global warming (Kyoto Agreement). In this respect, carbon dioxide capture and storage (CCS) is gradually becoming an important concept to reduce these greenhouse gas emissions, next to other options, such as the large scale use of renewable energy, nuclear energy and energy efficiency improvements.

The development of technology for $\mathrm{CO}_{2}$ capture and storage (CCS) could make a significant contribution towards the reduction of anthropogenic greenhouse gas emissions within a relatively short period.

The general concept of carbon dioxide capture and storage comprises three steps:

- Capture of $\mathrm{CO}_{2}$ : Power plants are the largest point sources of $\mathrm{CO}_{2}$ emissions to the atmosphere and hence $\mathrm{CO}_{2}$ capture from power plants can have a large impact on emission reduction. $\mathrm{CO}_{2}$ emissions from power production are around $30 \%$ of overall emissions. Large amounts of $\mathrm{CO}_{2}$ are emitted in diluted streams of flue gases at atmospheric pressure, as the fuel is usually burned in air. Other large single point sources of diluted $\mathrm{CO}_{2}$ are furnaces, industrial boilers and cement production plants. The emitted $\mathrm{CO}_{2}$ is captured at the source.

In order to simplify the ensuing steps of transport and storage a near pure $\mathrm{CO}_{2}$ product at an absolute pressure of 100 bar needs to be produced by the capture process. Therefore a compression step is also needed to achieve the right transport/storage conditions. 
- Transport of $\mathrm{CO}_{2}$ : Transport of $\mathrm{CO}_{2}$ is needed as the emissions of $\mathrm{CO}_{2}$ will not necessarily be at the same location as the storage site. A transport system (via pipelines and/or shipping) is therefore needed to link the $\mathrm{CO}_{2}$ sources to the $\mathrm{CO}_{2}$ storage sites.

- Storage of $\mathrm{CO}_{2}$ : Storage of $\mathrm{CO}_{2}$ should be such that it remains isolated from the atmosphere for a suitably long period. The options for this are mainly underground, i.e. (depleted) oil and gas fields, aquifers and deep seated coal bearing layers.

Various aspects and components of the CCS process chain have been researched over the past 15 years, both practically and theoretically. This has revealed that CCS can be a valuable part in the portfolio of technologies to reduce $\mathrm{CO}_{2}$-emissions. It is also accepted that capture, transport and underground storage of $\mathrm{CO}_{2}$ can be achieved using technologies which are commercially available. However, there is a need to adapt and optimise these technologies for cost effective CCS.

This report reviews the technological state-of-the-art of the various underground storage options. A separate chapter is dedicated to monitoring technology that is available for underground storage, another one to the injection processes and technologies. Some other areas of research, such as ocean storage, economics, health, safety and environmental aspects of $\mathrm{CO}_{2}$ injection and storage are not included in the report.

\section{GEOLOGICAL $\mathrm{CO}_{2}$ STORAGE OPTIONS}

Following the capture and transport processes, $\mathrm{CO}_{2}$ needs to be stored in order not to be emitted into the atmosphere. Storage in underground rock structures is one of the items towards which research is concentrated.

The main geological storage options are: oil and gas reservoirs, deep saline aquifers, deep seated coal beds (enhanced coal-bed methane recovery), caverns and mines.

The technologies for these storage options are at various stages of development. The know-how related to the exploration and production of hydrocarbons is of utmost importance, because these techniques are directly applicable to $\mathrm{CO}_{2}$ storage. EOR by injection of $\mathrm{CO}_{2}$ into oil fields has already been practiced in the USA as a commercial tertiary recovery technique, whereas the first commercial application of $\mathrm{CO}_{2}$ storage in an off-shore aquifer has been running successfully since 1996 at the Sleipner gas field in Norway. Other storage options are currently studied as well, as in the EU supported pilot of the storage of $\mathrm{CO}_{2}$ in a coal bed in Poland.

An important challenge is the estimation of the capacity of geological storage. Much work on the mapping of storage options has already been carried out during the past 10 years. A major contribution towards the storage potential in Europe was the EU supported GESTCO study. Based on this study the storage capacity is not a limiting factor. Altogether more than $40 \mathrm{Gt} \mathrm{CO}_{2}$ can be stored in (depleted) oil and gas fields in Western Europe and 150 to $1500 \mathrm{Gt} \mathrm{CO}_{2}$ of theoretical potential is estimated for deep saline aquifers in Western Europe $^{1}$ [IEA GHG (2005) Building the Cost Curves for $\mathrm{CO}_{2}$ Storage: European sector. Report Number 2005/2].

\section{OIL AND GAS FIELDS}

Oil and gas fields have proven their capability to hold oil and gas over long (geological) time periods and therefore can act as long-term storage sites for $\mathrm{CO}_{2}$ as well. This option is particularly interesting when one can take advantage of $\mathrm{CO}_{2}$ injection to effect enhanced oil (or gas) recovery. Improvement of gas recovery (EGR) with the help of $\mathrm{CO}_{2}$ injection is still in the phase of desk studies. In addition, the level of knowledge of oil and gas fields is high, which supports the predictability of the reservoir as a potential $\mathrm{CO}_{2}$ storage structure.

The theoretical storage potential is considerable; an estimate resulted in a theoretical potential of more than $40 \mathrm{Gt} \mathrm{CO}_{2}$ in European hydrocarbon reservoirs (IEA GHG, 2005), $7 \mathrm{Gt}$ of which can be stored in oil fields. A drawback of oil and gas fields is that the majority of them are at considerable distance (the North Sea region) from the $\mathrm{CO}_{2}$ emitting power plants.

There are no principle technical barriers for storage in gas fields although it has not been implemented to date. Storage of natural gas is routine business in many countries like the US, France and Germany. A pilot project for $\mathrm{CO}_{2}$ storage in gas fields has started in the Dutch sector of the North Sea (K12-B gas field). Underground storage of natural gas is competing for space with storage of $\mathrm{CO}_{2}$.

$\mathrm{CO}_{2}$ injection has been applied for many years already to enhance the production of oil from oil reservoirs (EOR), in particular in the United States. In conventional $\mathrm{CO}_{2}$-EOR, the main aim is to inject a minimum amount of $\mathrm{CO}_{2}$ to maximise oil production. Conversely, in the case of $\mathrm{CO}_{2}$ storage, one tries to inject the maximum amount of $\mathrm{CO}_{2}$ and possibly increase oil production. This difference is demonstrated in the Canadian Weyburn project, which is directed to the co-optimisation of oil production and $\mathrm{CO}_{2}$ injection. For the owners and the operator of the Weyburn oil field, increased oil production is paramount; while an international consortium is studying the aspects of optimising the net amount of injected $\mathrm{CO}_{2}$.

With regard to safety and environmental impact, particular attention should be directed to the integrity of the wells that were drilled for the exploitation of natural gas or oil. They might form locations of unintended $\mathrm{CO}_{2}$ leakage. Specific attention should also be directed to unintended fracturing of

(1) The estimate of the theoretical aquifer storage potential is marked by large uncertainty, which is caused by a lack of suitable data and by uncertainty in the aquifer storage concept that is applicable (physical trapping, dissolution, mineralization or a combination of these). 
the seal as a consequence of the pressure fluctuations in the reservoir and possible degradation of seal integrity due to reaction with $\mathrm{CO}_{2}$-loaded fluids.

\section{DEEP SALINE AQUIFERS}

This solution has great potential in terms of storage capacity, although the uncertainty in the available estimated potential is high. This is caused by the generally low level of knowledge for deep-seated saline aquifers. Due to the high salt content of these formations, they cannot be used as sources of drinking or irrigation water.

An estimate of the theoretical storage potential revealed a potential of 150 to $1500 \mathrm{Gt} \mathrm{CO}_{2}$ in West-European aquifers (IEA GHG, 2005). A major characterization and testing effort is called for, in order to qualify this type of aquifer for geological storage, especially onshore. The low level of reconnaissance will increase the lead times for the implementation of $\mathrm{CO}_{2}$ storage in saline aquifers.

The first large-scale $\mathrm{CO}_{2}$ storage plant injects $\mathrm{CO}_{2}$ in an aquifer, which is at a depth of 800 to $1000 \mathrm{~m}$ below the sea bottom (near the Sleipner gas field in the Norwegian North Sea).

\section{DEEP COAL SEAMS}

In recent years, the use of $\mathrm{CO}_{2}$ for Enhanced Coal-Bed Methane Recovery (ECBM) has attracted a lot of attention for some obvious reasons. The Earth's sedimentary basins contain an enormous amount of coal. The challenge is to unlock the coal-bed methane resources in an economically viable manner. One of the attractive aspects of ECBM is that for each molecule of gas produced; at least two $\mathrm{CO}_{2}$ molecules can be absorbed in the coal matrix. One of the main problems associated with developing ECBM is the low permeability of most unminable coals.

The theoretical $\mathrm{CO}_{2}$ storage potential of European coal seams is estimated at about 6 Gt (IEA GHG, 2005). In many instances the coal reserves are close to industrial centres with $\mathrm{CO}_{2}$ emitting power plants.

In general, the development of this storage technology is behind those of the other reservoirs. An ECBM pilot project, which is funded by the EC and industry, is running in Poland (RECOPOL).

\section{CAVERNS AND MINES}

Caverns in rock-salt and abandoned coal mines can serve as potential $\mathrm{CO}_{2}$ storage structures, although the storage capacity will be limited. Salt caverns might be used for temporary storage to buffer exhaust $\mathrm{CO}_{2}$ streams or to use $\mathrm{CO}_{2}$ for other commercial purposes. These structures are considered to be less suitable for long-term $\mathrm{CO}_{2}$ storage; at the same time they must compete with other applications like waste disposal.

Abandoned coal mines are present in the former German, British, Belgian and Dutch coal mining districts. These mined coal zones have increased permeability, which improves the $\mathrm{CO}_{2}$ injectivity. The sealing capacity of the overburden is however questionable. In Germany and Britain there is abundant evidence of gas leakage to the surface in the major coal mining areas, which makes $\mathrm{CO}_{2}$ storage in abandoned coal mines less attractive for these regions.

Final manuscript received in May 2005 